\section{(2) OPEN ACCESS}

\title{
Management of ventriculo-gallbladder shunt in the presence of gallstones
}

\author{
Sondus Alraee, ${ }^{1}$ Sahar Alshowmer, ${ }^{1}$ Mohammad Alnamshan, ${ }^{2}$ Moutasem Azzubi ${ }^{3}$
}

${ }^{1}$ College of Medicine, King Saud bin Abdulaziz University for Health Sciences, Riyadh, Saudi Arabia

${ }^{2}$ Department of Pediatric Surgery, National Guard Health Affairs, Riyadh, Saudi Arabia ${ }^{3}$ Department of Pediatric Neurosurgery, National Guard Health Affairs, Riyadh, Saudi Arabia

Correspondence to Dr Sondus Alraee; sondusalraee@gmail.com

Accepted 26 May 2020
D Check for updates

(c) BMJ Publishing Group Limited 2020. Re-use permitted under CC BY-NC. No commercial re-use. See rights and permissions. Published by BMJ.

To cite: Alraee $S$,

Alshowmer S, Alnamshan M, et al. BMJ Case Rep

2020:13:e234775

doi:10.1136/bcr-2020

234775

\section{SUMMARY}

Hydrocephalus is a prevalent health problem that is frequently encountered by paediatric neurosurgeons during infancy and childhood. We report a case of an 11-year-old boy with high cerebrospinal fluid protein hydrocephalus secondary to optic glioma that required a ventriculoperitoneal (VP) shunt. The patient had multiple failures of VP shunt and developed massive ascites. Alternatively, the hydrocephalus was treated by ventriculo-gallbladder (VG) shunt in the presence of sludge which was removed from the gallbladder before placement of the shunt. After VG shunt insertion, the patient expressed signs of infection with elevated liver profile, which emphasised the presence of gallstones. While the shunt was kept in its place without any complications, the gallstones were successfully removed by an endoscopic retrograde cholangiopancreatography. In conclusion, the presence of sludge is not a contraindication for VG shunt placement, and, if the VG shunt was complicated with gallstones, it could be treated without the need for cholecystectomy.

\section{BACKGROUND}

Hydrocephalus is an impairment in cerebrospinal fluid (CSF) physiological dynamics, which can lead to multiple complications and neurological deficits. ${ }^{1}$ During infancy and childhood, hydrocephalus is a prevalent health problem that is frequently encountered by paediatric neurosurgeons. ${ }^{2}$ When stratified by age groups, the global prevalence of hydrocephalus is $88 / 100000$ in the paediatric population. ${ }^{3}$ The standard care management of hydrocephalus is preferred at a specific surgical site, which is ventriculoperitoneal (VP) shunt. ${ }^{2}$ In case of unavailability or complications, other body cavities can be useful. Examples of alternative cavities are: the most common pleural cavity and cardiac atrium, and less common are gallbladder, stomach, ureters and Fallopian tubes. ${ }^{2}$ Endoscopic third ventriculostomy (ETV) is also an option for treating hydrocephalus. ${ }^{4}$ Gallbladder is a sterile organ that absorbs fluids and electrolytes and has the capability of maintaining a suitable intracranial pressure. ${ }^{5}$ Thus, the gallbladder has been used as an alternative cavity for CSF diversion. ${ }^{5}$ However, some early and late complications could occur with the ventriculo-gallbladder (VG) shunt and may lead to the malfunctioning of the shunt. ${ }^{6}$ These complications include shunt tract infection, ventricularsmall bowel fistula, biliary tract infection and proximal shunt obstruction. ${ }^{6}$ Another complication includes gallbladder atony which in long term could lead to gallstone formation. ${ }^{6}$ Presence of cholecystitis, intra-abdominal infections and gallstones are contraindications of VG shunt placement. ${ }^{78}$ In this report, we are describing a case of hydrocephalus secondary to optic glioma with a high CSF protein content that was treated by VG shunt in the presence of gallstones.

\section{CASE PRESENTATION}

This is a case of 11-year-old boy, who has a history of fall from the sixth floor and sustained severe traumatic brain injury when he was at 4 years of age. During trauma screening including CT brain, he was found to have multiple brain contusions and an incidental finding of extensive optic glioma. After that, an MRI brain showed that the optic glioma was very extensive in the brain parenchyma, to the point it was extending from both optic nerves through the optic chiasm and to the whole optic pathways bilaterally (figure 1). Moreover, it was extending to intraventricular system and to the sella and suprasellar region. Patient was managed and treated in the paediatric intensive care unit with conservative treatment for the head injury. The patient ended up with a Glasgow coma scale (GCS) of 8/15.

Due to his poor neurological status, with this extensive optic glioma, it was decided by paediatric neuro-oncology tumour board that there is no further treatment that can be offered to him. During his follow-up, he was found to have a significant

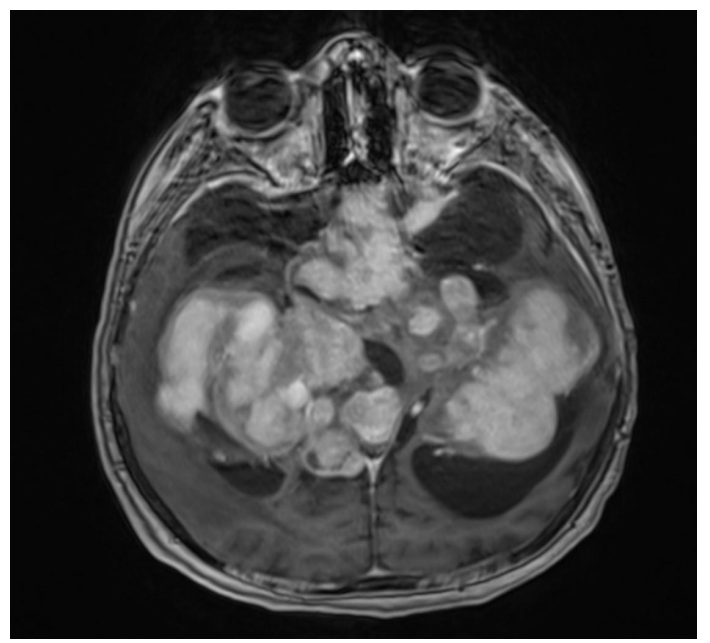

Figure 1 Brain MRI scan demonstrating the extent of optic glioma in the brain parenchyma. 


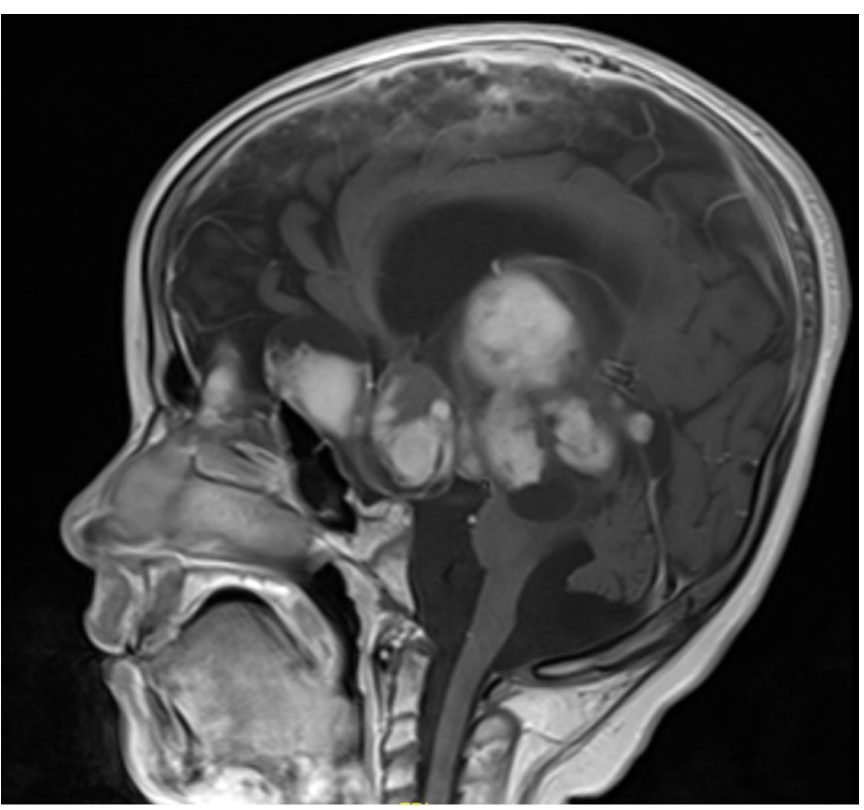

Figure 2 Brain MRI scan showing the location of optic glioma in the lateral ventricles, anterior and posterior part of the third ventricle.

increase in his head circumference which reached up to $74 \mathrm{~cm}$. The brain MRI was repeated and showed progression of the tumour size and the hydrocephalus; therefore, a VP shunt was inserted. After 4 months, the VP shunt was complicated by recurrent abdominal ascites due to scarring from previous abdominal exploratory surgery, and high protein in the CSF. This required us to do multiple revisions and tapping of the abdominal ascites by inserting a peg tail. At this point, he failed the management of multiple VP shunt revisions.

CSF protein was found most of the time to be more than $20 \mathrm{~g} / \mathrm{L}$, and he was required to have frequent periodic ascitic tapping almost every 3 weeks. Because of the high protein content of the CSF, other cavities for shunt placement were excluded. For example, pleural cavity was excluded to avoid pleural effusion and cardiac atrium was excluded to avoid thrombosis. Also, the brain endoscopic surgeries like ETV was excluded due to tumour location in the lateral ventricles, anterior, and posterior part of the third ventricle (figure 2). After all these factors, we decided to proceed with VG shunt. An ultrasound of the gallbladder was done, which represented a sludge in the gallbladder; however, there were no signs of inflammation or biliary dilatation. Laparoscopic insertion of VG shunt was established through inserting the distal end of the VP shunt into the gallbladder fundus with irrigation of the gallbladder using normal saline to clean it from the sludge. The patient tolerated the procedure well with no difficulties. Evaluation of the VG shunt patency has been done by a nuclear medicine study called a shunt patency test. In this test, a radiotracer was injected into the shunt reservoir and we measured the flow of CSF in the shunt and valves. The test showed that the radiotracer filled the gallbladder and after giving the patient a meal, the gallbladder contracted and the transit of the radiotracer activity was seen in the bowel loops, which indicated the patency of the VG shunt (figure 3). After 5 weeks of VG shunt placement, the patient presented to the emergency department with a 3-day history of fever, shortness of breath and presence of jaundice on examination.

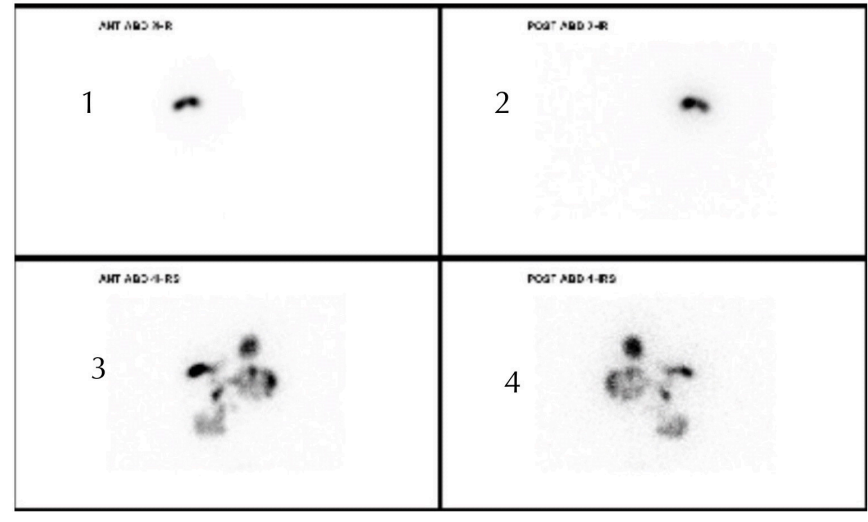

Figure 3 Shunt patency test after 4 hours of injecting the radiotracer. (1) Contrast in the gallbladder. (2) Contrast after giving a meal. (3) Contrast in the gallbladder and reaching the bowl. (4) Gallbladder completely empty and the tracer is in the small bowl.

\section{INVESTIGATIONS}

The patient was vitally stable and had a normal electrolyte profile. The complete blood count showed leucocytosis. Liver profile was ordered which showed an increase in the alkaline phosphate levels $482 \mathrm{U} / \mathrm{L}$, total bilirubin $60.8 \mu \mathrm{mol} / \mathrm{L}$, direct bilirubin $41.7 \mathrm{U} / \mathrm{L}$, aspartate aminotransferase of $134 \mathrm{U} / \mathrm{L}$ and gamma glutamic transferase $409 \mathrm{U} / \mathrm{L}$. For further investigation, an ultrasound of the abdomen was done, and it showed dilated intrahepatic bile ducts and common bile duct with gallbladder wall thickening and hyperemia; findings were concerning for cholecystitis/cholangitis. To further confirm the diagnosis, a magnetic resonance cholangiopancreatography was done. It showed cystic duct stones and common bile duct obstruction. Also, there were extrahepatic and intrahepatic biliary duct dilatation.

\section{TREATMENT}

An endoscopic retrograde cholangiopancreatography (ERCP) with sphincterotomy and stone extraction was performed, and a $7 \mathrm{~F}$ by $7 \mathrm{~mm}$ plastic stent was inserted with excellent bile drainage. The procedure was successfully done with no complications (figure 4). After the procedure, an abdominal X-ray was done to confirm the location of the shunt (figure 5).

\section{OUTCOME AND FOLLOW-UP}

The patient is still in follow-up for this condition and other comorbidities that sometimes require admission. After 12 months of follow-up, the liver profile showed normalisation in the levels of alkaline phosphate $141 \mathrm{U} / \mathrm{L}$, total bilirubin $7.3 \mu \mathrm{mol} / \mathrm{L}$, aspartate aminotransferase $50 \mathrm{U} / \mathrm{L}$ and alanine transferase $83 \mathrm{U} / \mathrm{L}$. A brain CT scan was also done showing stable hydrocephalus.

\section{DISCUSSION}

It is known that VP shunt is the most common site for extracranial drainage of CSF. However, many complications have been reported, such as abdominal pseudocyst, massive ascites, intraabdominal pathologies and high non-absorbable proteins in the CSF fluid like in some malignancies and infections. ${ }^{9}{ }^{10}$ In our case, the child developed massive ascites that required multiple paracentesis probably due to the high protein content of his CSF. Kamat et al described in his study the levels of CSF proteins when quantified in relation to the VP shunt functioning. ${ }^{11} \mathrm{He}$ found that with higher levels of protein, reaching up to $2.0 \mathrm{~g} / \mathrm{L}$ in the CSF, the risk of VP shunt blockage increased. ${ }^{11}$ Massive ascites 


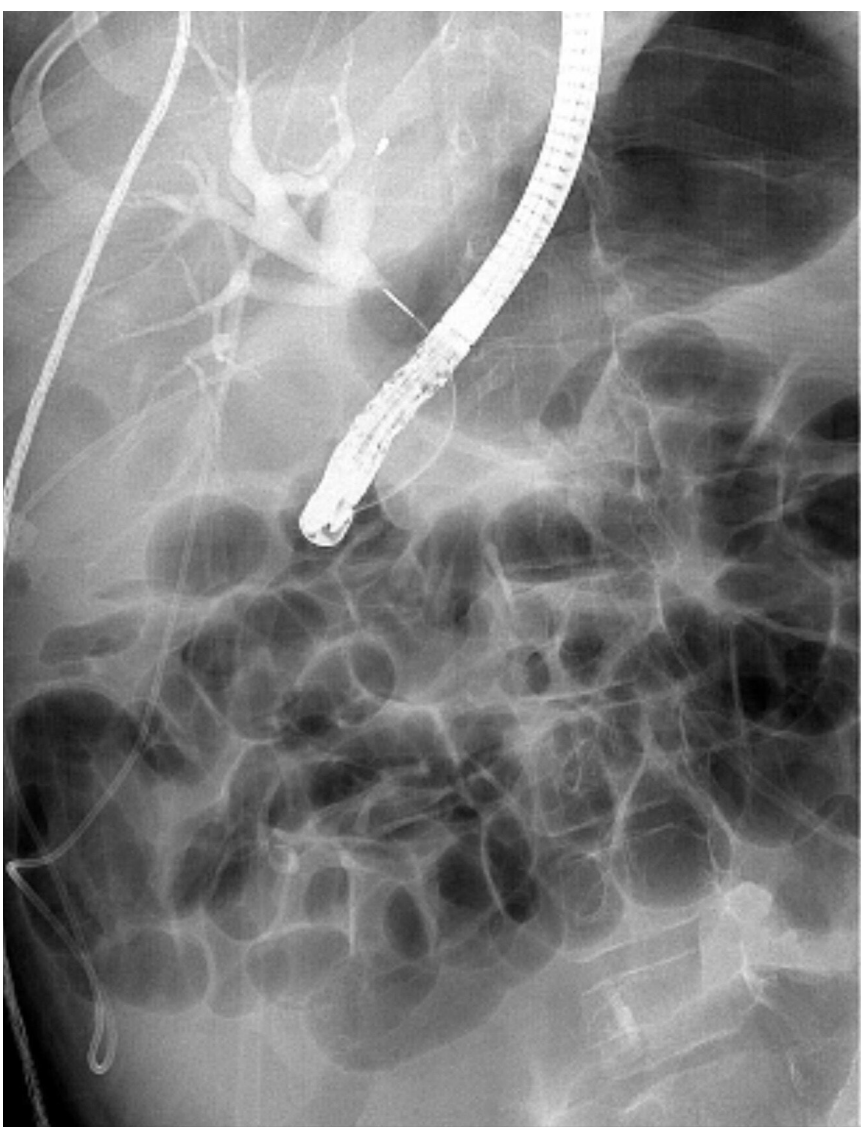

Figure 4 Endoscopic retrograde cholangiopancreatography showing the dilatation of the intrahepatic and extrahepatic duct with no obvious filling defect.

is a rare complication of VP shunt; however, in cases of some brain tumours such as optic pathway gliomas, it can be present. ${ }^{11}$ It is suggested that high levels of CSF protein in optic glioma are due to its wide exposure to CSF space, which allows the tumour proteins to easily pass through the CSF and lead to poor

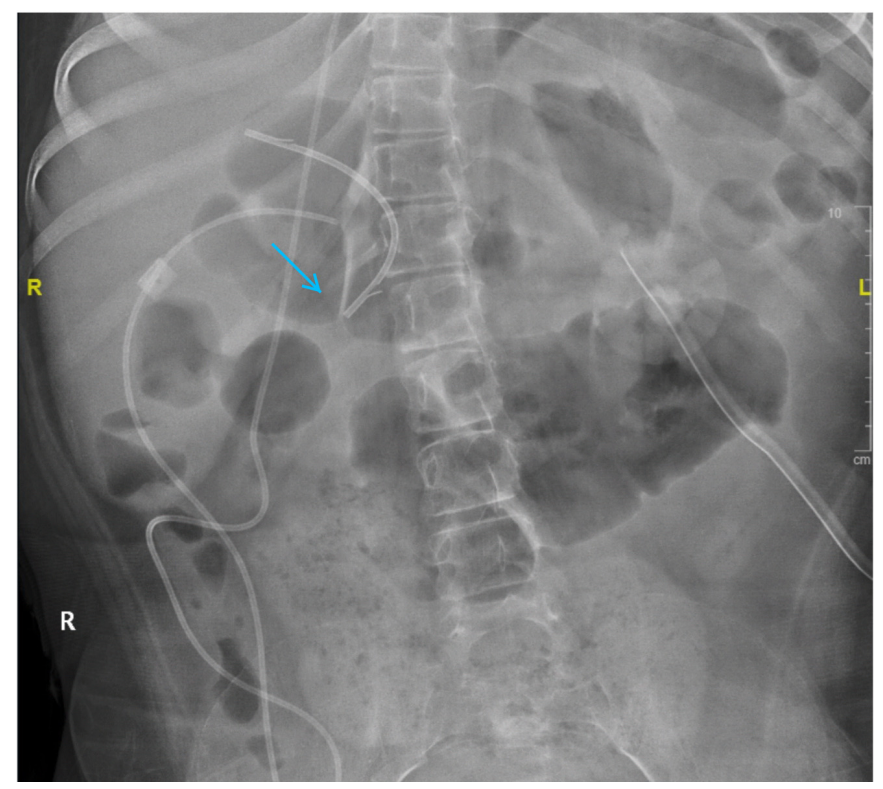

Figure 5 Abdominal X-ray showing the shunt in the gallbladder with the biliary stent (blue arrow) in place. absorption and obstruction of the VP shunt. ${ }^{12}$ In this case, other cavities can be used, such as atrial cavity or gallbladder cavity. Smith et al were the first one who introduced and described the drainage of the CSF into the gallbladder in $1959 .{ }^{13}$ Gallbladder is a sterile organ that acts as a receptor for CSF fluid, and it has a distinctive lytic feature of the bile by breaking down the CSF proteins, which makes it a good choice for drainage. ${ }^{5}$ Some reports have described if cholelithiasis in the shunt tubing after insertion of VG shunt was present, this requires the patient to undergo cholecystectomy as a standard care for gallstones and conversion of the shunt to a VP shunt. ${ }^{910}$ Later in the follow-up, our patient developed obstructive jaundice with stones in the common bile duct as a complication which is considered an indication for removal of VG shunt. However, due to the limited options in his case, the VG shunt was the most suitable reservoir for our patient. We tried to manage it by flushing the stones out by ERCP and stenting, and then the VG shunt was successfully maintained without removing the gallbladder. This was evident by following up on the patient 12 months after the procedure. In conclusion, obstructive jaundice and choledocholithiasis that results as a complication of VG shunt placement can be managed by ERCP and stone extraction with preservation of the shunt in its place, especially when other sites are limited.

\section{Learning points}

Ventriculo-gallbladder (VG) shunt can treat refractory hydrocephalus with high cerebrospinal fluid protein.

- The presence of sludge in the gallbladder with no signs of chronic inflammation is not a contraindication for VG shunt placement.

- If the patient develops jaundice post VG shunt, it can be treated by endoscopic retrograde cholangiopancreatography and stenting.

Contributors Supervised by MAN and MA. The patient was under the care of MAN and MA. The report was written by SA and SAls.

Funding The authors have not declared a specific grant for this research from any funding agency in the public, commercial or not-for-profit sectors.

Competing interests None declared.

Patient consent for publication Parental/guardian consent obtained.

Provenance and peer review Not commissioned; externally peer reviewed.

Open access This is an open access article distributed in accordance with the Creative Commons Attribution Non Commercial (CC BY-NC 4.0) license, which permits others to distribute, remix, adapt, build upon this work non-commercially, and license their derivative works on different terms, provided the original work is properly cited and the use is non-commercial. See: http://creativecommons.org/ licenses/by-nc/4.0/.

\section{REFERENCES}

1 Grigorean VT, Sandu AM, Popescu M, et al. Our initial experience with ventriculoepiplooic shunt in treatment of hydrocephalus in two centers. Neurol Neurochir Pol 2017;51:290-8.

2 Ketoff JA, Klein RL, Maukkassa KF. Ventricular cholecystic shunts in children. J Pediatr Surg 1997;32:181-3.

3 Isaacs AM, Riva-Cambrin J, Yavin D, et al. Age-Specific global epidemiology of hydrocephalus: systematic review, metanalysis and global birth surveillance. PLoS One 2018;13:e0204926.

4 Gholampour S, Bahmani M, Shariati A. Comparing the efficiency of two treatment methods of hydrocephalus: shunt implantation and endoscopic third ventriculostomy. Basic Clin Neurosci 2019;10:185-98.

5 Olavarria G, Reitman AJ, Goldman S, et al. Post-shunt ascites in infants with optic chiasmal hypothalamic astrocytoma: role of ventricular gallbladder shunt. Childs Nerv Syst 2005;21:382-4.

6 West KW, Turner MK, Vane DW, et al. Ventricular gallbladder shunts: an alternative procedure in hydrocephalus. J Pediatr Surg 1987;22:609-12. 


\section{Reminder of important clinical lesson}

7 Pal K, Jindal V. Ventriculo cholecystic shunt in the management of hydrocephalus. Indian Pediatr 2007:44:435-7.

8 Guclu B, Hicdonmez T, Adilay U, et al. Successful application of the VentriculoGallbladder shunt: a salvage procedure. Turk Neurosurg 2020;30:138-40.

9 Fountas KN, Kassam MA, Grigorian AA. A rare, delayed complication of a ventriculogallbladder shunt. Case report and review of the literature. Neurosurg Focus 2007:22:E12.

10 Surfield GA, Klein RL. Case report of symptomatic cholelithiasis after ventricular cholecystic shunt. J Pediatr Surg 2006;41:1933-4.
11 Kamat AS, Gretschel A, Vlok AJ, et al. CSF protein concentration associated with ventriculoperitoneal shunt obstruction in tuberculous meningitis. Int I Tuberc Lung Dis 2018;22:788-92

12 West GA, Berger MS, Geyer JR. Childhood optic pathway tumors associated with ascites following ventriculoperitoneal shunt placement. Pediatr Neurosurg 1994;21:254-9.

13 Smith GW, Moretz WH, Pritchard WL, et al. A new treatment for hydrocephalus. Surg Forum 1958;9:701-5.

Copyright 2020 BMJ Publishing Group. All rights reserved. For permission to reuse any of this content visit

https://www.bmj.com/company/products-services/rights-and-licensing/permissions/

BMJ Case Report Fellows may re-use this article for personal use and teaching without any further permission.

Become a Fellow of BMJ Case Reports today and you can:

- Submit as many cases as you like

- Enjoy fast sympathetic peer review and rapid publication of accepted articles

- Access all the published articles

- Re-use any of the published material for personal use and teaching without further permission

\section{Customer Service}

If you have any further queries about your subscription, please contact our customer services team on +44 (0) 2071111105 or via email at support@bmj.com.

Visit casereports.bmj.com for more articles like this and to become a Fellow 